\title{
DESIGN AND DEVELOPMENT OF A TEST RIG TO ESTIMATE FATIGUE LIFE OF THE TIMING BELT OF I. C. ENGINE
}

\author{
Ramrajesh H. Deshmukh ${ }^{1}$, Mukund B. Patwardhan ${ }^{2}$ \\ ${ }^{1}$ Student, Design Engineering, Walchand college of Engineering, Maharashtra, India \\ ${ }^{2}$ Professor, Mechanical Engineering, Walchand college of Engineering, Maharashtra, India
}

\begin{abstract}
Timing belt mechanism of an internal combustion engine synchronizes the rotation of the crankshaft and camshaft. The power developed in I.C. engine, some power of that is utilized to operate timing belt mechanism. Timing valves are operated by camshaft with lever and spring mechanism. Engine valve should open and close at proper time during each inlet and exhaust strokes of the cylinder. The failure of timing belt in I.C. engine leads to problem to valve timing and this can cause collision between valves and piston in engines. It can causing serious engine damage by bending valves and breaking piston and it leads to complete breakdown or catastrophic engine failure.

A large number of factors have influence on timing belt drive's lifetime: wear, amount of transmitted power, operating environment, coaxiality of shafts and belt pulleys, handling before and during assembly and others. Failure of belt most frequently occurs because of damage of belt's and belt pulley's teeth or damage of tractive element due to wear and fatigue. Considering their purpose and very important role in transmission of power, motion and valve timing, it is necessary to know fatigue life of timing belt. The study was thus needed to analyze fatigue failure of timing belt. The paper includes designing and development of a test rig for estimation fatigue life of timing belt. Test rig is developed based on ISO and Automotive industry standards. The study involves observation of change of physical properties, wear and geometric parameters of the belt. Thereafter tooth deflection and tooth root strain is obtained by calculation. Tooth deflection and tooth root strain play important role in fatigue of the belt.
\end{abstract}

Keywords: Timing belt mechanism, Timing belt, Physical properties, Geometric parameter, Wear, Tooth deflection, tooth root strain.

\section{INTRODUCTION}

A timing belt drive is relatively young drive designed by Case in 1946. It was rubber with trapezoidal profile. Timing belt drives are a relatively new concept in power transmission, accepted nowadays in all areas of industry. Teeth, equally spaced on the inner side of timing belts, come into contact with the belt pulleys teeth through their grooves. By this meshing, a connection between the belt and belt pulley is achieved and torque is transmitted. Timing belts are used for timing systems that transmit power and assure an accurate synchronous rotation without slippage. One of the main fields of application of synchronous belts is overhead camshaft drive in automobile engines. The fatigue failure of synchronous belts is complex because there are many factors that affect belt failure such as tight side and slack side tensions, pulley diameter, belt pitch, pitch difference between belt and pulley, belt stiffness, angle of wrap.

The present paper reports the design and development of test rig for the fatigue testing of timing belt in laboratory conditions in which fatigue life is calculated by applying different speed and load. The load is given by using eddy current dynamometer which is monitored by P.C. based data acquisition system. Analysis of belt is done by profile images at regular interval, photographs, stiffness test and wears measurement.

\subsection{Timing Belt Mechanism}

Timing belt mechanism in I.C. Engine consists of crankshaft, camshaft, crankshaft pulley, camshaft pulley, timing belt tension pulley and timing belt. A timing belt mechanism of an internal combustion engine synchronizes the rotation of the crankshaft and the camshafts so that the engine's valves open and close at the proper times during each cylinder's intake and exhaust strokes. The camshaft operates timing valves through valve lever mechanism with springs.

There are two types of timing belt mechanism

- $\mathrm{SOHC}$

- DOHC. 

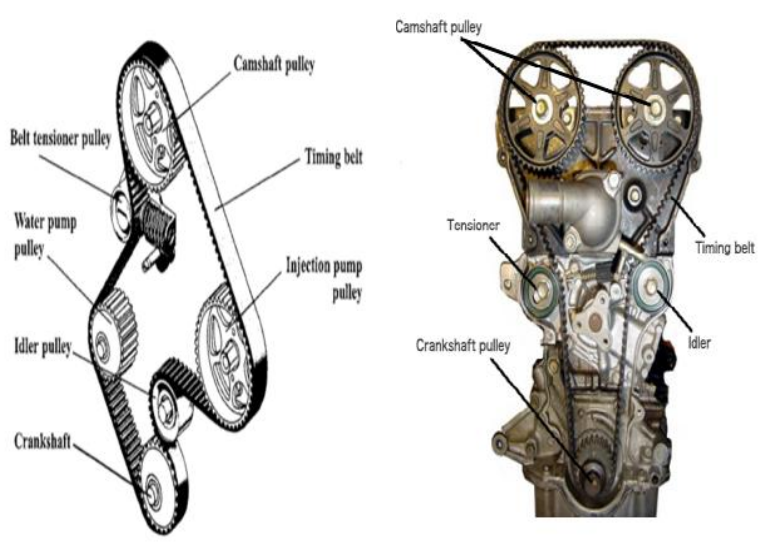

Fig-1: Timing belt mechanism

As number of cylinder increases timing mechanism shifted from SOHC to DOHC because inertia forces increases so it will require large torque which can be distributed to two shafts in DOHC.

\subsection{Timing Belt}

The automotive timing belts are classified into two type trapezoidal tooth and curvilinear tooth. A timing belt is typically rubber with high-tensile fibers (e.g. fiberglass or Kevlar) running through the length of the belt as tension members.

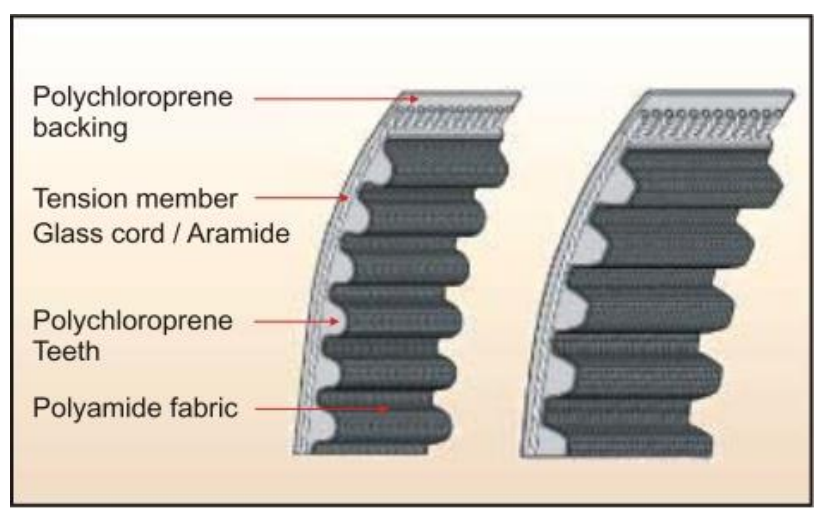

Fig-2: Construction of timing belt

\subsection{Objective of the Work}

The objective of the work is as follows,

- To design and develop experimental setup.

- $\quad$ Test the belt at different speed and load condition.

- To find out tooth deflection and tooth root strain.

\section{TEST CELL SETUP}

The following figure shows the test cell set up where the fatigue test is conducted. The load on camshaft is controlled through Eddy-current dynamometer by the operator from outside the test cell.

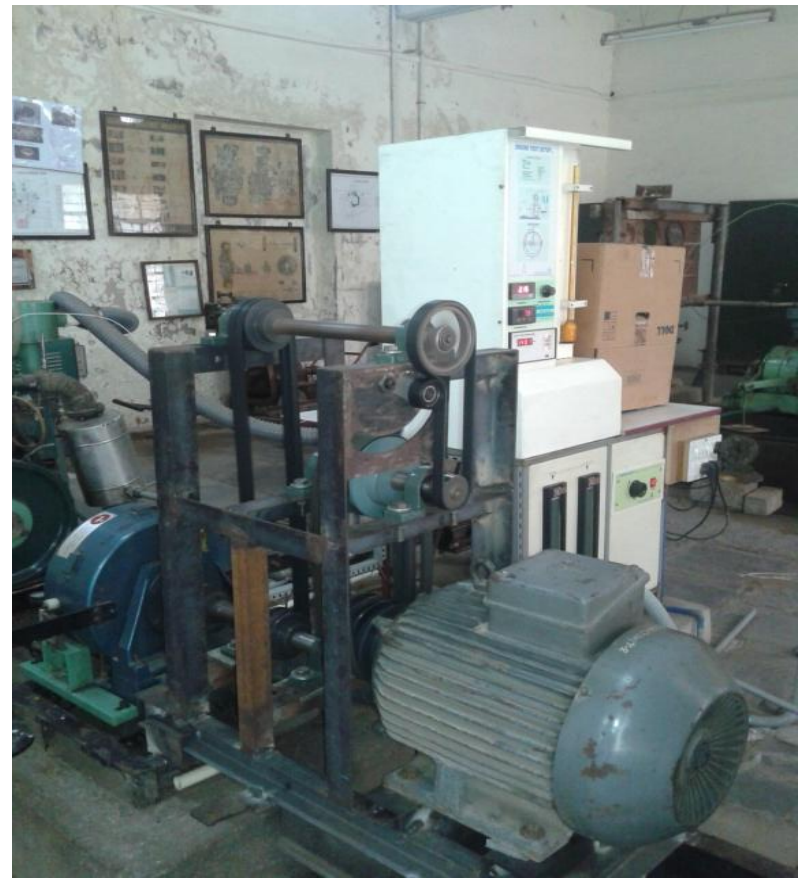

Fig-3: Test cell setup [6]

\section{EXPERIMENTAL ANALYSIS}

The fatigue life of belt tested with the developed test rig which is designed for various speed and load conditions. The testing is done at standard environmental conditions. Physical properties, wear measurement and geometric parameter of belt is noted at regular interval during testing. The fatigue testing of belt is done according to AIS-077.

\subsection{Wear}

Failure most frequently occurs because of damage of belts teeth or damage of tractive element due to wear. During testing timing belt runs over timing pulleys and tension pulleys. At the beginning of the coupling, the belt tooth top has contact with broadside surface of pulley with line contact. Due to interference, the belt tooth encroaches on the broadside surface of the belt pulley. The friction between belt teeth and pulley teeth causes wear of belt. Wear of belt is tested by measuring the weight of belt. Weight measurement of belt is shown below

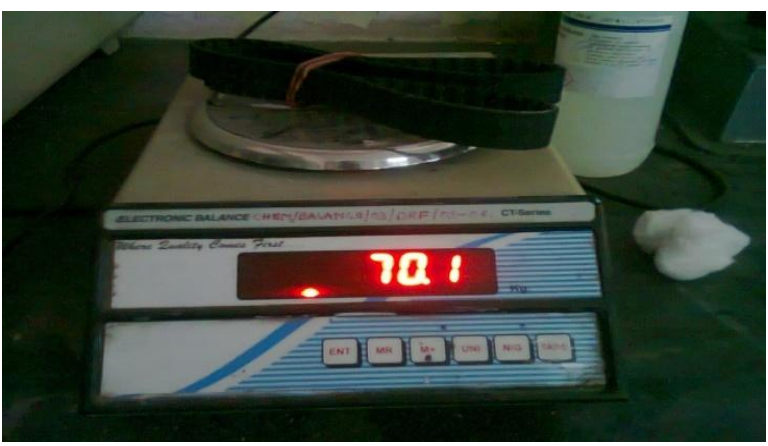

Fig-4: Weight measurement

Changes in the weight are listed in following table 1 
Table-1: Variation of Weight of belt

\begin{tabular}{|l|l|l|l|}
\hline $\begin{array}{l}\text { Time } \\
\text { (hour) }\end{array}$ & $\begin{array}{l}\text { Weight } \\
(\text { Gram })\end{array}$ & $\begin{array}{l}\text { Time } \\
\text { (hour) }\end{array}$ & $\begin{array}{l}\text { Weight } \\
\text { (gram) }\end{array}$ \\
\hline 0 & 70.1 & 110 & 69.7 \\
\hline 10 & 70.1 & 120 & 69.5 \\
\hline 20 & 70.1 & 130 & 69.4 \\
\hline 30 & 70 & 140 & 69.3 \\
\hline 40 & 70 & 150 & 69.2 \\
\hline 50 & 70 & 160 & 69.1 \\
\hline 60 & 69.9 & 170 & 69 \\
\hline 70 & 69.9 & 180 & 68.8 \\
\hline 80 & 69.9 & 190 & 68.5 \\
\hline 90 & 69.8 & 200 & 68.4 \\
\hline 100 & 69.7 & & \\
\hline
\end{tabular}

\subsection{Geometric Parameter}

Geometric parameter such as pitch of belt, tooth thickness, belt total height and belt groove thickness is worn out during testing of belt. Due to change in geometric parameters of the belt the redistribution of forces occurs. There raises a need for additional tensioning of the belt, which directly influences the service life of the drive.

Geometric parameters are measured after every fifty hours running of the belt. They are measured by using profile projector. The values of geometric parameters are listed in table 2

Table-2: Variation of geometric parameter

\begin{tabular}{|l|l|l|l|l|}
\hline $\begin{array}{l}\text { Time } \\
\text { (hour) }\end{array}$ & $\begin{array}{l}\text { Total } \\
\text { height } \\
(\mathrm{mm})\end{array}$ & $\begin{array}{l}\text { Tooth } \\
\text { height } \\
(\mathrm{mm})\end{array}$ & $\begin{array}{l}\text { Tooth } \\
\text { groove } \\
(\mathrm{mm})\end{array}$ & $\begin{array}{l}\text { Pitch } \\
(\mathrm{mm})\end{array}$ \\
\hline 0 & 4.25 & 2 & 4.85 & 9.52 \\
\hline 50 & 4.23 & 1.97 & 4.83 & 9.55 \\
\hline 100 & 4.19 & 1.93 & 4.80 & 9.59 \\
\hline 150 & 4.12 & 1.88 & 5.40 & 9.75 \\
\hline 200 & 4.04 & 1.82 & 6 & 9.91 \\
\hline
\end{tabular}

\subsection{Stiffness}

Stiffness is defined as the ability of the material to resist deformation under the action of external load. The slope of load Vs deflection graph within elastic limit is called as stiffness. Load Vs deflection curve is obtained from universal testing machine of machine model TUE-C-400 of maximum load capacity $400 \mathrm{KN}$. Stiffness of belt is tested after every fifty hours of running of belt.

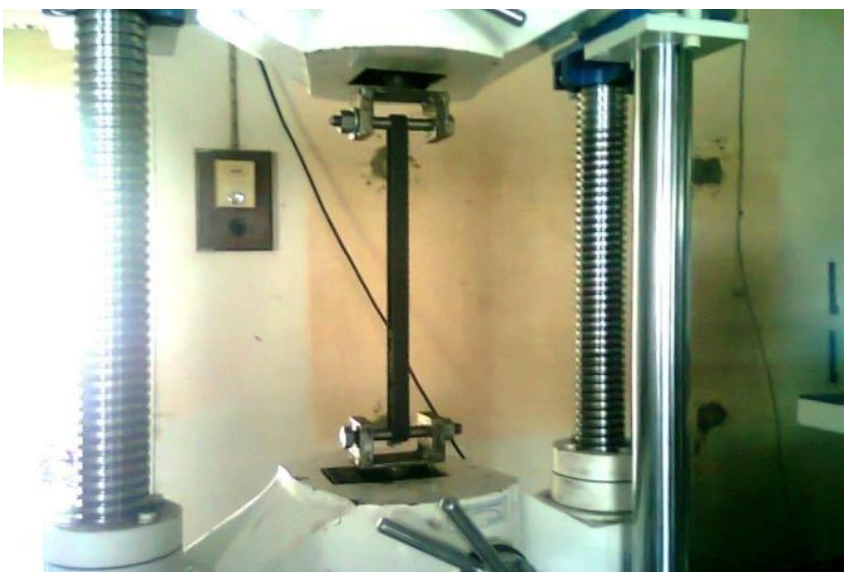

Fig-5: Stiffness testing of belt

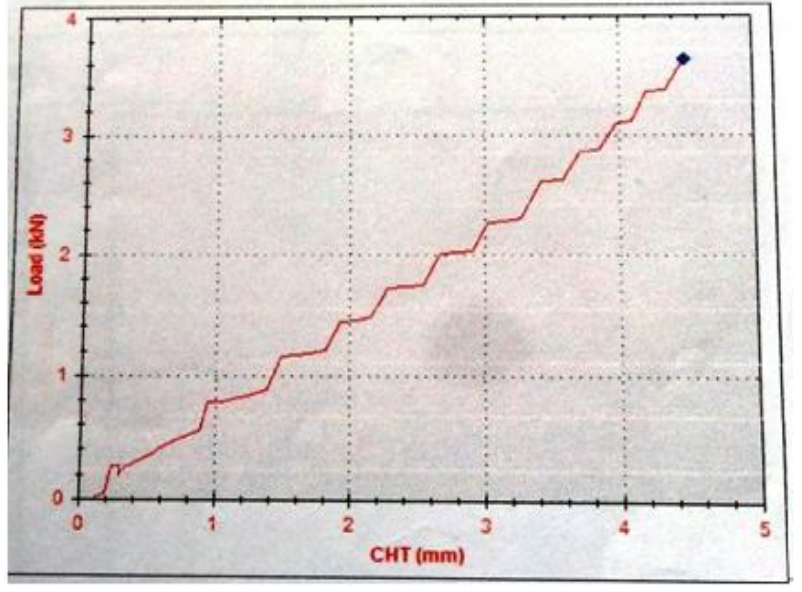

Fig-6: Load Vs deflection Graph

The values of stiffness are listed in table 3

Table-3: Variation of pitch of belt

\begin{tabular}{|l|l|l|l|l|l|}
\hline $\begin{array}{l}\text { Time } \\
\text { (hour) }\end{array}$ & 0 & 50 & 100 & 150 & 200 \\
\hline $\begin{array}{l}\text { Stiffness } \\
(\text { KN/mm } \\
\text { per } \\
\text { pitch) }\end{array}$ & 35.94 & 30.63 & 22.705 & 18.711 & 14.463 \\
\hline
\end{tabular}

\section{RESULTS AND DISCUSSIONS}

As we have already discussed in this paper that testing is done according to AIS-077 standard. The Timing belt is tested using developed setup and the performance is shown in terms of graph. Also tooth deflection and tooth root strain is calculated and graph is plotted.

\subsection{Wear Analysis}

From table 1 the experimental data is analyzed and graph of Weight Vs time is plotted. 


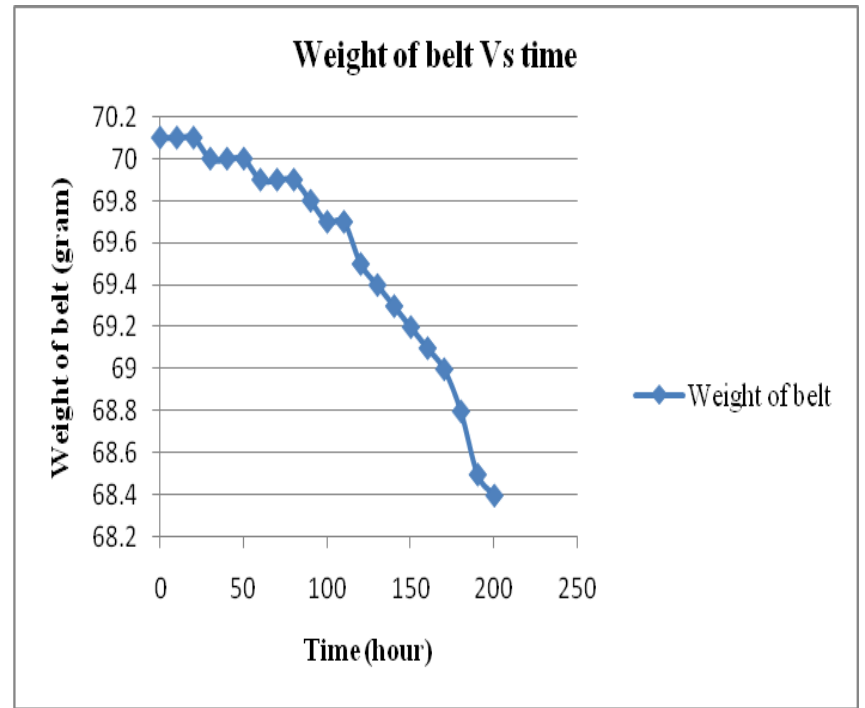

Chart-1: Weight of belt Vs Time

\subsection{Effect on Geometric Parameters of the Belt}

From table 2 the experimental data are analyzed and graph of Change in geometric parameters Vs time is plotted. The graph of Change in geometric parameter $\mathrm{Vs}$ time is as follow

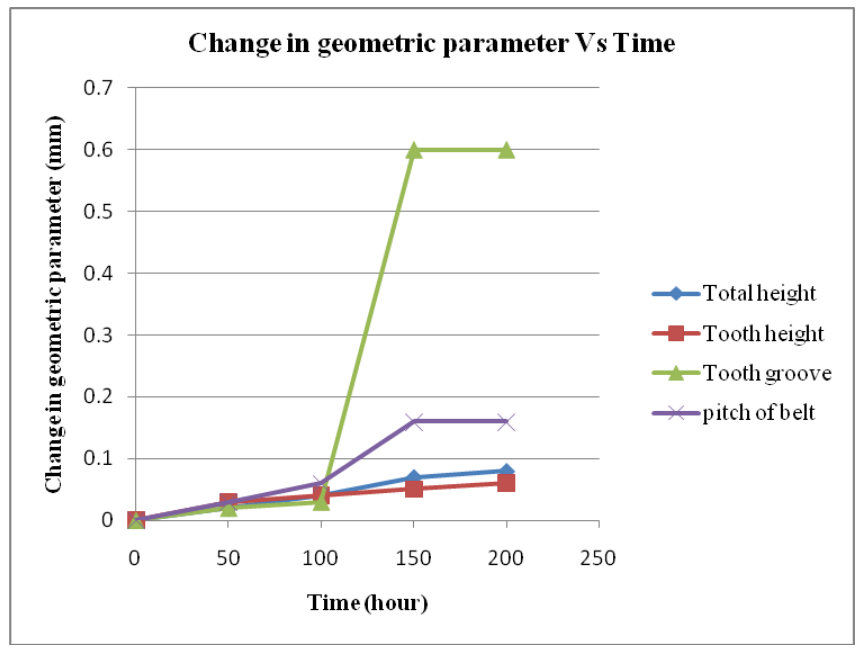

Chart-2: Change in geometric parameter Vs Time

\subsection{Effect on Stiffness of Belt}

From table 3 the experimental data are analyzed and graph of stiffness Vs time is plotted. The graph of stiffness Vs time is as follow

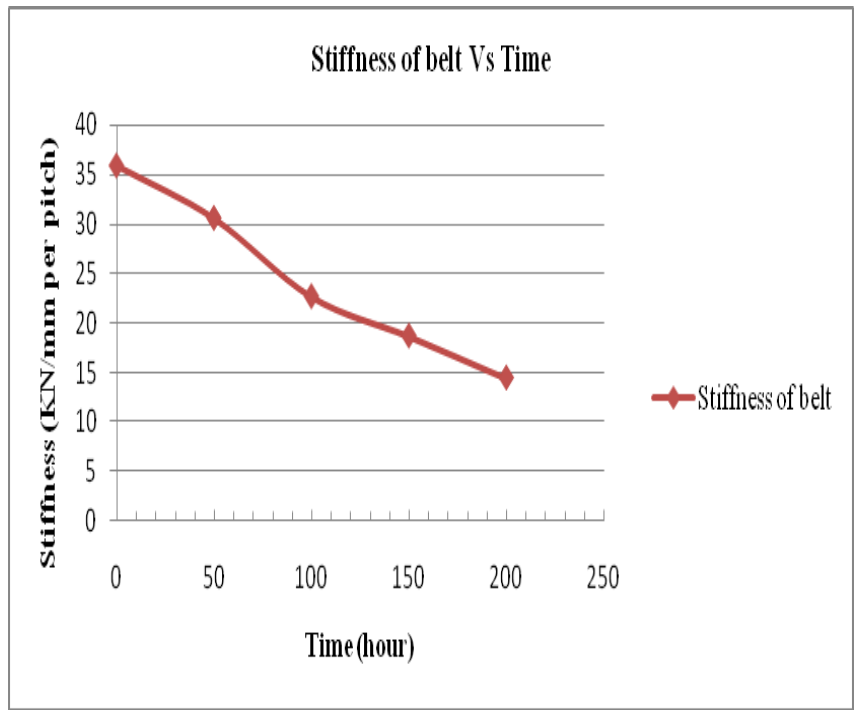

Chart-3: Stiffness of belt Vs Time

\subsection{Tooth Deflection and Tooth Root Strain}

The change in parameters affects the tooth root strain, stress and tooth deflection. By using the geometric parameters values from table 2, the tooth deflection and tooth root strain at driving entry and at driven exit are calculated.

$$
\begin{aligned}
\text { - } \quad \mathrm{Q} & =\frac{\mathrm{T}_{\mathrm{t}} \times \mathrm{P}}{\pi \times \mathrm{R}_{\mathrm{p}}} \\
\text { - } \quad \lambda & =\frac{Q}{k} \\
\text { - } \quad \mathrm{M} & =\mathrm{Q} \times t_{d} \\
\text { - } \quad & \Psi=\frac{\lambda}{t_{d}}+\frac{6 M}{K \times t_{w}^{2}}
\end{aligned}
$$

Where,

Q- Tooth load,

Tt- Tension in belt,

P- Pitch of belt,

$t_{d}$ - tooth height,

K- Stiffness of belt,

M- Bending moment,

$\mathrm{t}_{\mathrm{w}}$ - Belt width,

$\lambda$ - Tooth deflection,

$\Psi$ - Tooth root strain.

The tooth deflection and tooth root strains at driving entry and at driven exit are listed in the table below.

Table-4: Tooth deflection at driving entry and driven exit

\begin{tabular}{|l|l|l|l|l|l|}
\hline $\begin{array}{l}\text { Time } \\
\text { (hour) }\end{array}$ & 0 & 50 & 100 & 150 & 200 \\
\hline $\begin{array}{l}\text { Deflection } \\
\text { at driving } \\
\text { entry }\end{array}$ & 0.4418 & 0.499 & 0.6468 & 1.023 & 1.114 \\
\hline $\begin{array}{l}\text { Deflection } \\
\text { at Driven } \\
\text { exit }\end{array}$ & 0.2140 & 0.249 & 0.3234 & 0.5115 & 0.557 \\
\hline
\end{tabular}




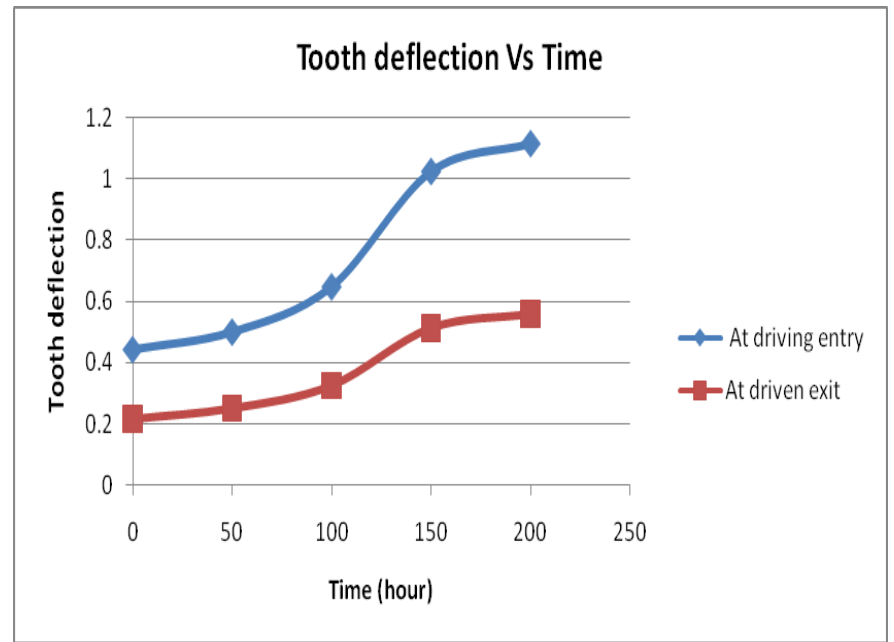

Chart-4: Tooth deflection Vs Time

Table-6: Tooth root strain at driving entry and at driven exit

\begin{tabular}{|l|l|l|l|l|l|}
\hline $\begin{array}{l}\text { Time } \\
\text { (hour) }\end{array}$ & 0 & 50 & 100 & 150 & 200 \\
\hline $\begin{array}{l}\text { Tooth root } \\
\text { strain at } \\
\begin{array}{l}\text { Driving } \\
\text { entry }\end{array}\end{array}$ & 0.2282 & 0.2758 & 0.3677 & 0.5788 & 0.6127 \\
\hline $\begin{array}{l}\text { Tooth root } \\
\text { strain at } \\
\text { driven exit }\end{array}$ & 0.1143 & 0.1379 & 0.1838 & 0.2894 & 0.3363 \\
\hline
\end{tabular}

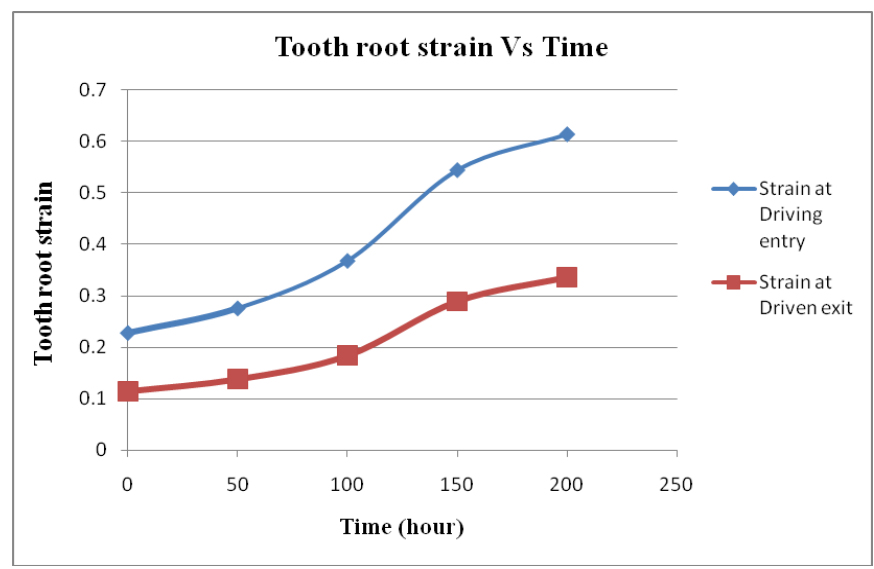

Chart-4: Tooth root strain Vs Time

\subsection{Observation of Fatigue Failure}

Fatigue failure of the belt is observed during testing

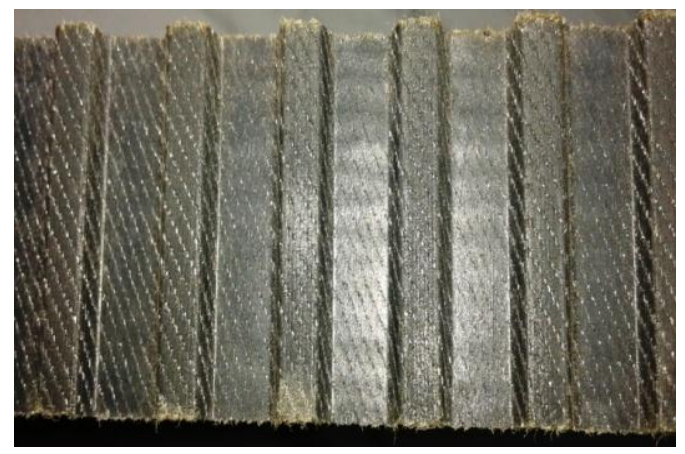

(a)

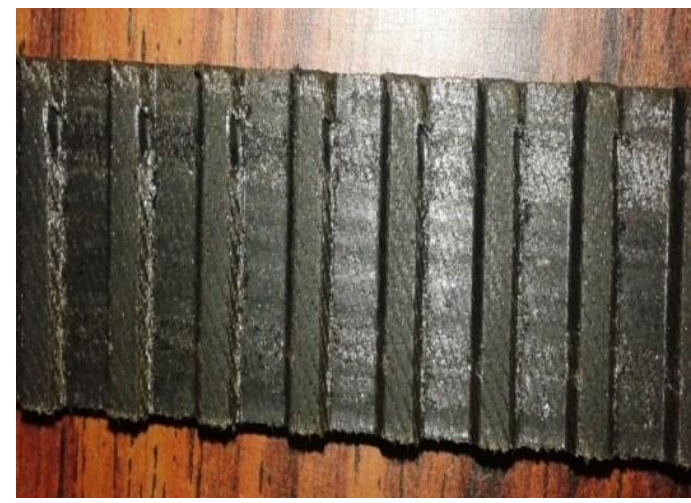

(b)

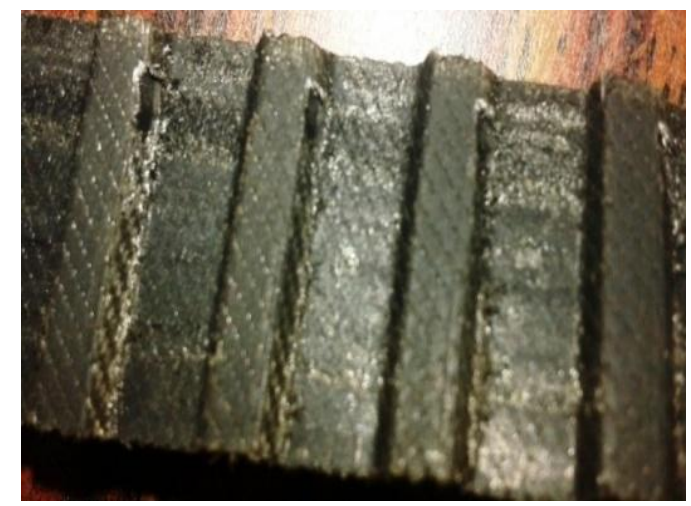

(c)

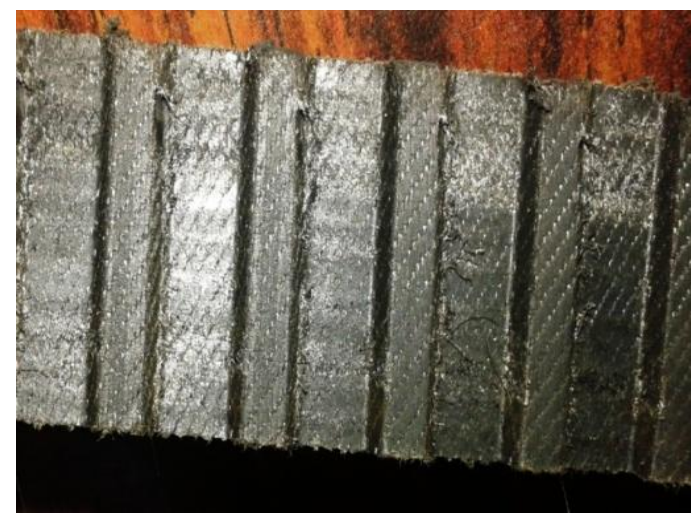

(d)

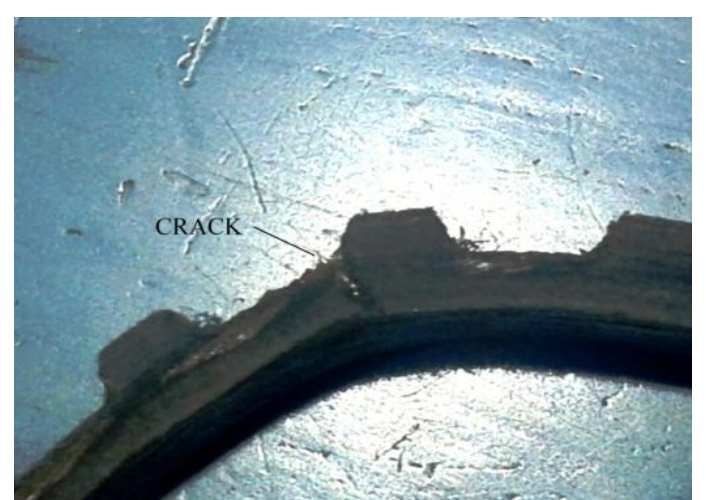

(e)

Fig-6: Images of belt during fatigue testing (a) At beginning, (b) After fifty hours, (c) After hundred hours, (d) After 150 hours, (e) After 200 hours. 


\section{CONCLUSION}

- The tooth deflection Vs time graph shows as time passes the tooth deflection increases. The tooth root strain Vs time graph shows increase in tooth root strain as time passes. The increase in tooth deflections and tooth root strain increases stress concentration at root of the tooth. The increase in stress concentration produces crack. It finally results into fatigue failure of the belt.

- It is found after the test that the fatigue testing machine designed and developed is able to provide all the testing requirements and test conditions. As recommended by AIS-077 standards the minimum belt life in individual results is found satisfactory, as it exceeds the recommended figure.

\section{REFERENCES}

[1]. AIS-077."Specification for Automotive Timing Belts," The Automotive Research Association of India, December 2005.

[2]. T. H. C. Childs, K. W. Dalgarno, A. J. Day and R. B. Moore. "Automotive Timing Belt Life and a User Design Guide," SAGE, May 1998, pp. 409-420.

[3]. K. W. Dalgarno, A. J. Day, T. H. C. Childs, R. B. Moore. "Stiffness loss of Synchronous Belts," Elsevier, 1998, pp.217-221.

[4]. H. Lizuka, K. Watanabe and S. Mashimo. "Observation of Fatigue Failure in Synchronous Belts," Elsevier, March 1994, pp. 783-790.

[5]. Blaza Stojanovic, Slobodan Tanasijevic, Nenad Marjanovic, Mirko Blagojevic. "Failure Analysis of the Timing Belt Drives," Serbian tribology Society, May 2011, pp. 210-215.

[6]. tables/Drive/Timing belts.

http://www.Roymech.co.ukm/useful

\section{BIOGRAPHIES}

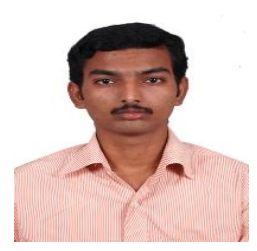

Mr. Ramrajesh H. Deshmukh, pursuing M. Tech in Design Engineering from Walchand college of engineering, Sangli.

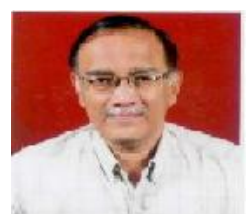

Mr. Mukund B. Patwardhan working as Professor in Walchand College of Engineering, Sangli. 